\title{
Application of the exergy index as ecological indicator of organically enrichment areas in the Mar Menor lagoon (south-eastern Spain)
}

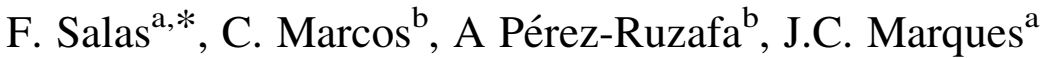 \\ ${ }^{\mathrm{a}}$ Department of Zoology, Faculty of Sciences and Technology, IMAR_Institute of Marine Research, University of Coimbra, \\ 3004-517 Coimbra. Portugal \\ ${ }^{\mathrm{b}}$ Department of Ecology and Hidrology, Faculty of Biology, University of Murcia, 30100 Murcia, Spain
}

Received 4 December 2003

\begin{abstract}
The increase of stress induced changes in marine environments caused by different types of marine pollution made necessary the search for indicators that assist in assessing pollution effects at the community level. The main goals, with a view to an effective management, are the early detection and evaluation of environmental responses to pollution and to avoid or mitigate negative impacts that different uses may generate.

Exergy has been considered as a promising indicator of ecosystem integrity, acquiring a considerable interest in the context of systems ecology.

In this research we have tested the capability of exergy (both the exergy index and specific exergy) alongside other diversity indices (Shannon and Margalef indices) of distinguishing organically enriched areas in a Mediterranean coastal lagoon (El Mar Menor).

Results show that the exergy index and specific exergy were able to give useful information on community structure, although they were not capable of distinguishing high and poor organically enriched areas or affected by any other type of pollution. Diversity indices were more sensitive to organic pollution.

We may say that the exergy and specific exergy are still not applicable as the only ecological indicators in a generalized way in the field of environmental management. Therefore, they still require further application in a wider range of geographical areas and in different conditions in order to study more widely the properties of exergy as an ecological indicator.

(C) 2005 Elsevier Ltd. All rights reserved.
\end{abstract}

\footnotetext{
* Corresponding author. Tel.: +351 239836386; fax: +351 239823603.

E-mail address: fuen@ci.uc.pt (F. Salas).
} 


\section{Introduction}

The development of coastal zones throughout the world induced an increasing environmental stress on biological communities and living resources located in such areas. As a consequence, there is a major need for methodologies and techniques suitable to evaluate changes ongoing in marine habitats, with emphasis on the development of indicators that may allow an early detection of environmental degradation processes [1].

Different marine environmental studies usually employ the use of indices and biological indicators as tools for detecting environmental changes and assess environmental quality due to their ability to integrate information from the environment and the fluctuations that take place in it. Thus, the use of biological indices and bioindicators is generally considered as one of the most reliable and simple options to detect the results of pollution on ecosystems [2].

O'Connor and Dweling [3] proposed five criteria to define a suitable index of ecosystem degradation. These are as follows: The index should be (1) relevant, (2) simple and easily understood by laymen, (3) scientifically defensible, (4) quantitative, and (5) acceptable in terms of costs.

From a more scientific point of view, the characteristics that would define a good indicator are handling easiness, sensibility to small variations of pollution, specificity regarding the type of pollution, independence of reference states, applicability in extensive geographical areas and in the greatest possible number of communities or ecological environments.

It is possible to distinguish different types of indicators based on different organization levels, such us the level of an organism, population, a community or an entire ecosystem. The most reliable and excellent indicators are those based on the more general properties of populations, communities and on processes involved in ecosystem's functioning [4,5]. The search of novel ecological indicators is extremely important in environmental studies.

Exergy is a concept derived from thermodynamics that may be seen as energy with a built in measure of quality (corresponding to thermodynamic information, which expresses the distance between a given state of an ecosystem and what the system would be at thermodynamic equilibrium) [6]. In other words, the exergy of an ecosystem at thermodynamic equilibrium would be zero. This means that, during ecological succession, exergy is used to build up biomass, which in turn stores exergy, and therefore exergy represents a measure of the biomass structure plus the information embedded in the biomass [7].

In a trophic network, biomass and exergy will flow between ecosystem compartments, supporting different processes by which exergy is both degraded (respiration) and stored (growth production) in different forms of biomass belonging to different trophic levels. More complex organisms have more built in information and are further away from thermodynamic equilibrium than simpler organisms. Therefore, more complex organisms also have more built in exergy (thermodynamic information) in their biomass than the simpler ones. On the other hand, ecological succession drives from more simple to more complex ecosystems, which seem at a given point to reach a sort of balance between keeping a given structure, emerging for the optimal use of the available resources, and modifying the structure, adapting it to a permanently changing environment.

If the total biomass in the system remains constant then exergy variations will rely upon its structural complexity. specific exergy is defined as exergy/biomass. Both exergy and specific exergy may be used as indicator in environmental management. It might be advisable to use them complementary [8].

What is the meaning of exergy and specific exergy in describing the condition of an ecosystem? From the theory, it is reasonable to hypothesise that there is a relation between the exergy values and other 
Table 1

Expected trends in the variation of the exergy index, specific exergy and several ecosystems properties

Lower values of the exergy index and specific exergy

Lower biodiversity

Lower functional redundancy

Lower b]uffer capacity and resilience

Loss complex ecosystems
Higher values of the exergy index and specific exergy

Higher biodiversity

Higher functional redundancy

Higher buffer capacity and resilience

More complex ecosystems

ecosystem characteristics like biodiversity, community structure, buffer capacity or resilience. In Table 1, we indicate what trends we should expect in the variation of the exergy based ecological indicators and several ecosystem properties [9].

Exergy has been considered as a promising indicator of ecosystem integrity by several authors [10-12], acquiring a considerable interest in the context of systems ecology. Actually, exergy has been applied as indicator of the state of ecosystems in a number of European lakes, mainly through the studies of Jørgensen [13,14], and Nielsen [15,16]. The lakes have been investigated in connection with natural or human induced changes of the lake ecosystems, such as eutrophication and biomanipulation. In addition, two other works investigated the relations between exergy based indices and biodiversity in a freshwater system and an estuary, respectively $[8,17]$. Results showed that exergy based indices appeared to be able to provide useful information regarding the state of the systems.

Nevertheless, the acceptance of exergy as ecological indicator requires tests of its applicability in a wider range of geographical areas and different environments, establishing the necessary gantries between theoretical concepts and their empirical application. The objective of the present study is therefore to analyse the properties of exergy as a possible indicator of marine pollution using an extensive data set on the Mar Menor lagoon (Mediterranean Sea) biological communities.

\section{Materials and methods}

\subsection{Study site}

The Mar Menor is a coastal lagoon with an area of $135 \mathrm{~km}^{2}$. The lagoon is connected to the Mediterranean at some points by channels through which the water exchange takes place with the open sea (Fig. 1).

The Mar Menor communities are adapted to more extreme temperatures and salinities than those found in the open sea. This coastal lagoon presents an environmental heterogeneity with different types of organic pollution. So, some areas are affected by: (1) urban direct dumping with the development of the nitrophyle communities dominated by Ulvae species. (2) Dumping or zone under the influence of harbours. (3) Zones with high levels of organic matter in the sediment coming from the primary production and the biological cycle of the macrophyte meadows (Caulerpa prolifera). This macrophyte was introduced in the lagoon as a result of the dredging in one of the channels at the beginning of the 1970s, growing rapidly around the whole lagoon, phenomenon which has been accelerated in the last years.

That $C$. prolifera growing has led an increment of the organic matter in the sediment. Such increment, although it has a natural origin, has become to mean important consequences in the communities, with 


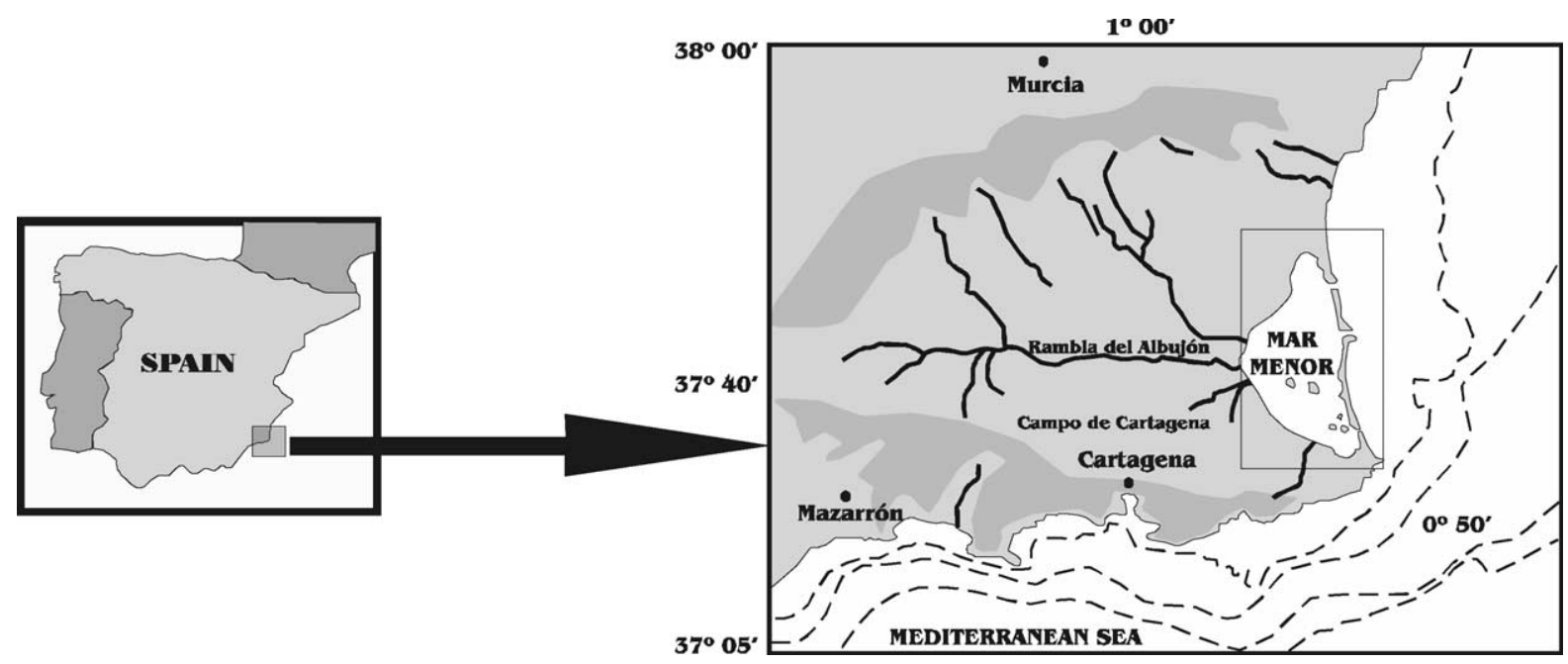

Fig. 1. Location of the Mar Menor lagoon.

a general impoverishment of fauna. In that sense, the named increment can be considered an authentic pollution as it is understood by the GESAMP [18]. (4) Zones with low input of organic matter in the soft substrates $(>1 \%)(\mathrm{M} 3, \mathrm{M} 9, \mathrm{M} 11)$ and on rocky bottoms (M1, and M5).

\subsection{Sampling stations}

Eleven sampling stations were located on rocky and soft substrates along the lagoon at sites representative of the different biocenosis and main polluted areas (Fig. 2). In some of the sampling stations, samples were taken seasonally (A: July, B: November, C: February, D: May) in order to evaluate the independence of different ecological indices with regard to seasonal variations. The characteristics of the sampling stations are summarised in Table 2.

\subsection{Environmental factors}

The following water and sediment parameters were measured each time, corresponding to each biological sample: temperature, salinity, dissolved oxygen, $\mathrm{pH}$, and suspended materials in the water column, and additionally granulometry, organic matter and heavy metal content in the sediments.

Water samples were collected from a vessel with hydrographic bottles (Niskin's types) or by scuba divers. Salinity was measured in situ through the Knudsen method, while dissolved oxygen was measured using a field oxygen meter (Orbisphere model 27141). Temperature and $\mathrm{pH}$ were also measured in situ using a graduated thermometer and a field $\mathrm{pH}$ meter, while materials suspended in the water were determined by weighing after filtration.

Scuba divers using PVC corers took sediment samples, and granulometric analysis was carried out following the hydrometer of Bouyoucos method [19-21]. Additionally, the Walkey \& Black method [22] was used to determine levels of organic carbon and organic matter content. Heavy metals content, 


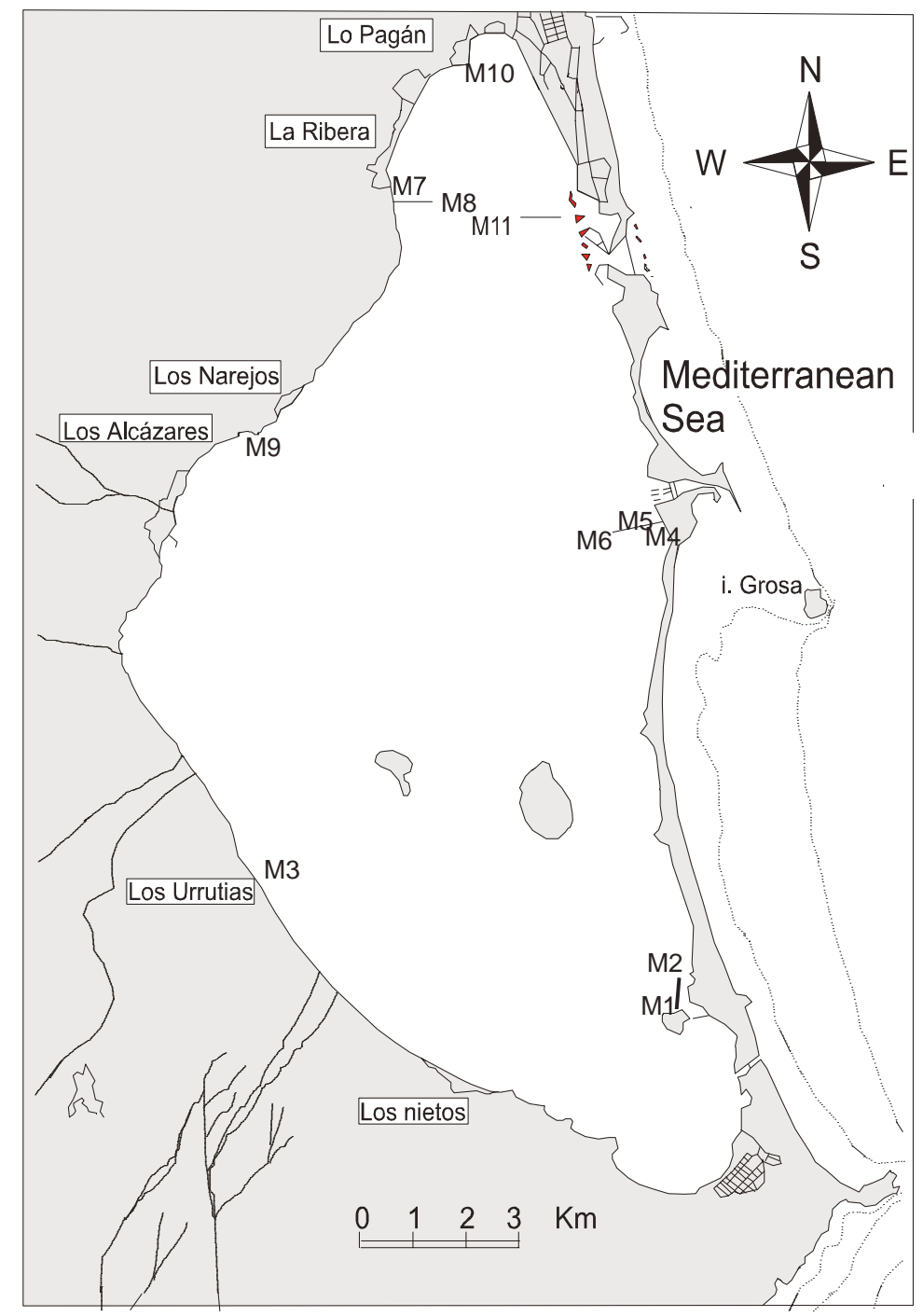

Fig. 2. Location of the different stations.

which in the case of Mar Menor was basically originated from old mining exploitations, is stable through time in the sediments. Therefore, we used data previous obtained by Guerrero [23].

The wave exposure of each sampling station has been measured following the methodology employed by Keddy [24], based on the fetch, speed and frequency of the wind [25].

\subsection{Biological samples}

Divers collected biological samples from both soft bottoms and rocky areas, moving along transepts perpendicular to the coastline and also in precise spots corresponding to the sampling stations. Each biological sample corresponded to $400 \mathrm{~cm}^{2}$. Afterwards, the samples were sieved 
Table 2

Characteristics of the different stations utilised in this study

\begin{tabular}{llll}
\hline Station & Type of substratum & Depth $(\mathrm{m})$ & Community \\
\hline M1A & Rocky & 0.75 & Photophilous seaweeds \\
M1B & Rocky & 0.70 & Photophilous seaweeds \\
M1C & Rocky & 0.50 & Photophilous seaweeds \\
M1D & Rocky & 0.70 & Photophilous seaweeds \\
M2D & Muddy & 2.50 & Cymodocea-Caulerpa meadow \\
M3D & Sandy & 1.30 & Cymodocea meadow \\
M4D & Rocky & 0.00 & Area intertidal \\
M5B & Rocky & 2.50 & Photophilous seaweeds \\
M5C & Rocky & 2.40 & Photophilous seaweeds \\
M5D & Rocky & 2.50 & Photophilous seaweeds \\
M6A & Sandy & 5.00 & Cymodocea-Caulerpa meadow \\
M6C & Sandy & 5.00 & Cymodocea-Caulerpa meadow \\
M6D & Sandy & 5.10 & Cymodocea-Caulerpa meadow \\
M7D & Rocky & 0.10 & Nitrophilous \\
M8D & Sandy & 0.34 & Cymodocea meadow \\
M9D & Sandy & 0.50 & Area with phoraneids \\
M10D & Rocky & 0.10 & Nitrophilous \\
M11D & Sandy/muddy & 3.50 & Dredged area \\
\hline
\end{tabular}

through a $500 \mu \mathrm{m}$ mesh and preserved in $4 \%$ solution of formaldehyde in seawater. Later, animals were separated, identified into 123 different taxa belonging to four high taxonomic groups (polychaetes, gastropods, bivalves an crustaceans). When possible, individuals collected were identified to the species level, counted, and posteriorly weighed (ash free dry weight). Table 3 shows a summary table with the total number of individuals, total number of species, and the identification of dominant species.

\subsection{Data analysis}

As stated above, in this paper we aimed to compare the properties of exergy and diversity, a more conventional ecological indicator, in elucidating about the state of a given ecosystem.

\subsubsection{Exergy estimations}

A brief description of the derivation of the exergy concept is provided by Marques et al. [9]. Recently [14], it has been derived from the previous formulation that an approximate estimation of exergy may be given by

$$
\mathrm{EX}=T \sum \beta_{i} C_{i}
$$

where $T$ is the absolute temperature, $C_{i}$ is the concentration in the ecosystem of component $i$ (e.g. biomass of a given taxonomic group or functional group per unit of surface or of volume), $\beta_{i}$ is a factor able to express roughly the quantity of information embedded in the genome of the organisms. Detritus was chosen as reference level, i.e. $\beta_{i}=1$, and therefore exergy embodied in biomass of different types of organisms is expressed in detritus energy equivalents. 
Table 3

Summary table showing ecological information (B: Bivalve; G: Gastropode; Cr Crustacean; Po: Polychaeta)

\begin{tabular}{|c|c|c|c|}
\hline Station & $S$ & $N$ & Dominant species (taxonomic group) \\
\hline M1A & 34 & 7077 & $\begin{array}{l}\text { Leptochelia savignyi }(\mathrm{Cr}) \\
\text { Caprella mitis }(\mathrm{Cr})\end{array}$ \\
\hline M1B & 33 & 681 & $\begin{array}{l}\text { Tanais dulongii }(\mathrm{Cr}) \\
\text { Pholoe minuta }(\mathrm{Po})\end{array}$ \\
\hline M1C & 34 & 5063 & $\begin{array}{l}\text { Leptochelia savignyi }(\mathrm{Cr}) \\
\text { Caprella mitis }(\mathrm{Cr})\end{array}$ \\
\hline M1D & 37 & 4146 & Caprella mitis $(\mathrm{Cr})$ \\
\hline M3D & 18 & 204 & $\begin{array}{l}\text { Cymodoce truncata }(\mathrm{Cr}) \\
\text { Bittium reticulatum }(\mathrm{G}) \\
\text { Bittium paludosum }(\mathrm{G})\end{array}$ \\
\hline M2D & 12 & 176 & Heteromastus filiformis (Po) \\
\hline M4D & 15 & 1017 & $\begin{array}{l}\text { Hyale perieri }(\mathrm{Cr}) \\
\text { Mytilaster minimus }(\mathrm{B})\end{array}$ \\
\hline M6A & 1 & 6 & Heteromastus filiformis (Po) \\
\hline M5B & 32 & 2994 & $\begin{array}{l}\text { Bittium reticulatum }(\mathrm{G}) \\
\text { Bittium jardertinum antonium }(\mathrm{G})\end{array}$ \\
\hline M5C & 24 & 1158 & $\begin{array}{l}\text { Bittium paludosum }(\mathrm{G}) \\
\text { Bittium jardertinum antonium }(\mathrm{G})\end{array}$ \\
\hline M6C & 9 & 89 & Heteromastus filiformis (Po) \\
\hline M5D & 26 & 1513 & Bittium reticulatum $(\mathrm{G})$ \\
\hline M6D & 7 & 124 & Heteromastus filiformis (Po) \\
\hline M7C & 21 & 2949 & Tanais dulongii $(\mathrm{Cr})$ \\
\hline M8C & 25 & 307 & $\begin{array}{l}\text { Bittium jardertinum antonium }(\mathrm{G}) \\
\text { Cymodoce truncata }(\mathrm{Cr})\end{array}$ \\
\hline M9 & 16 & 109 & $\begin{array}{l}\text { Glicera capitata }(\mathrm{Po}) \\
\text { Caulleriella alata }(\mathrm{Po})\end{array}$ \\
\hline M11 & 32 & 427 & Venerupis aurea (B) \\
\hline M10C & 10 & 164 & $\begin{array}{l}\text { Leptochelia savignyi }(\mathrm{Cr}) \\
\text { Siphonecetes sabatieri }(\mathrm{Cr})\end{array}$ \\
\hline
\end{tabular}

This new formulation of exergy, referred in first place as Modern exergy [14] does not correspond to the strict thermodynamic definition, but provides nevertheless an approximation of exergy values. In this sense, it was proposed to call it exergy index [9]. This formulation allows estimating empirically the exergy index from normal sets of ecological data, e.g. organism's biomass, provided that $\beta_{i}$ value for the different types of organisms is known.

Marques et al. [8] suggested the use of nuclear DNA ( $C$-values) content to evaluate the parameter $\beta$, assuming the DNA content as a measure of the information carried in its genome, acquired throughout the evolutionary process. On the other hand, Fonseca et al. [26] in accordance with the studies of MacGregor [27], Gold et al. [28] and Levin [29] claim that similar organisms in complexity may have significantly different nuclear DNA content and at higher evolutionary levels, genome size losses correspondence to the increase in structural complexity of organisms due to the presence of repetitive DNA sequences. Thus, non-repetitive DNA content, rather than the total genome should better evaluates organism complexity. Therefore, it could be assumed that to each adjacent triplet of nucleotides from non-repetitive DNA corresponds a transcribed RNA-signal (from regulatory genes or structural genes). 
Hence, the non-repetitive DNA could be considered as an approximate estimation (although rough) of the overall 'coding capacity' of the genome and used in the evaluation of the parameter $\beta$. For this reason, Fonseca et al. [25] propose that, instead of $C$-values to estimate weighing factors $\beta$ for each species, the lowest (known) $C$-value in different groups of organisms is preferable.

The minimum DNA contents (lowest $C$-values) of several groups used in the estimation of the $\beta$ parameter are given in Table 4.

Specific exergy is given by:

$$
\mathrm{SpEx}=\mathrm{Ex}_{\text {tot }} / \mathrm{Biom}_{\mathrm{tot}}
$$

What is the justification of using indicators like the exergy index and specific exergy? The criticism that biology and ecology as a whole are lacking universal laws and predictive theory is frequent [30]. Although we may still have no solution to this question, it has been argued [31] that it should at least be possible to propose a promising direction for ecological thinking, contributing to build some fragments of a theoretical framework. Thermodynamics has been widely applied in ecosystem theory since input, output, and cycling of mass and energy constitute the basis of ecological processes without exception. In this sense, the goal of the present paper, in a certain extent, is also to test a thermodynamic hypothesis using it to interpret empirical ecological results.

Table 4

Example of values regarding the number of genes and cell types and corresponding weighing factor $(\beta)$ to estimate the exergy index

\begin{tabular}{|c|c|c|c|c|}
\hline Organisms & $10^{-12} \mathrm{~g}$ DNA/cell & Number of genes & Number of cell types & Weighing factor \\
\hline detritus & 0 & 0 & 0 & 1 \\
\hline Bacteria & 0.005 & 600 & $1-2$ & 2 \\
\hline Algae & 0.009 & 850 & $6-8$ & 25 \\
\hline Fungus & 0.03 & 3000 & $6-7$ & 3 \\
\hline Insects & - & - & - & 70 \\
\hline Crustaceans & - & - & - & 230 \\
\hline Annelids worms & 20 & 100,000 & 60 & 50 \\
\hline Molluscs & - & - & - & 280 \\
\hline Gastropods & & & & 450 \\
\hline Bivalves & & & & 760 \\
\hline Echinoderms & - & - & - & 360 \\
\hline Fish & 20 & $100,000-120,000$ & 70 & 260 \\
\hline Birds & - & 120,000 & - & 1100 \\
\hline Amphibians & - & 120,000 & - & 800 \\
\hline Reptiles & - & 120,000 & - & 1100 \\
\hline Mammals & 50 & 140,000 & 100 & 2000 \\
\hline Human & 90 & 250,000 & 254 & 1300 \\
\hline
\end{tabular}

Values of weighting factors, which are related to the quality of the biomass in the system, are based on the number of information genes. The Exergy content of the organic matter in the various organisms is compared with Exergy contained in detritus. Estimations were carried out according to the method described by Jørgensen et al. [14], based on analytical work [26] and on literature sources $[29,35]$. Several organisms are considered, even those not concerned with the present work, in order to provide an idea of $\beta$ factors variation within the living world. 


\subsubsection{Diversity estimations}

There are many difficulties involved in understanding the dynamics of diversity. In fact, it is not pessimistic if we claim that it is impossible to find a 'diversity index' capable to express the dynamics of mixed populations, exhibiting stabilized values through space and time. Anyhow, diversity is usually comprehended as a quality indicator of the state of the ecosystem, and there are a few relations regarding the composition of natural communities that exhibit relatively low spatial (local) and temporal variability, and constitute therefore suitable possibilities to be used as diversity measures.

We chose to use the Shannon-Wiener and Margalef indices to compare their values with estimations of the exergy index, to analyse the coherence of these different types of indicators in describing the state of the ecosystem.

Shannon-Wiener index. It is based on the information theory. It assumes that individuals are sampled at random, out of an 'indefinitely large' community, and that all the species are represented in the sample.

The index takes this shape:

$$
H^{\prime}=-\sum p_{\mathrm{i}} \log _{2} p_{\mathrm{i}}
$$

where $p_{i}$ is the proportion of individuals found in the species $i$. In the sample, the real value of $p_{i}$ is unknown, but it is estimated through the ratio $N_{i} / N$, for $N_{i}$ is the number of individuals of the species $i$ and $N$ the total number of individuals.

The units for the index depend on the $\log$ used. So, for $\log _{2}$, the unit is bits/individual; 'natural bels' and 'nat' for loge; and 'decimal digits' and 'decits' for log 10.

\subsection{Margalef index}

The Margalef index quantifies the diversity relating specific richness to the total number of individuals.

$$
D=(S-1) / \log _{2} N
$$

For $S$ is the number of species and $N$ the total number of individuals.

Moreover, the Pearson's correlation $(P \leq 0.05)$ was used in order to evaluate the relationships between the values of the exergy index and diversity indices and environmental factors.

A MDS analysis was performed with the PRIMER 5 (Software package from Plymouth Marine Laboratory, UK). Data (species abundance) were transformed by double square root and a Bray Curtis similarity matrix was calculated. Stress values were shown for each MDS plot to indicate the goodness of representation of differences among samples. An ANOSIM analysis was carried out to determine how separate the stations groups were on a scale of 0 (groups are indistinguishable) and 1 (all similarities within groups are less than any similarities between groups).

\section{Results}

The values of the different environmental parameters analyzed in each station are shown in Table 5. It is clear that the areas mostly affected by organic enrichment correspond to stations M2 and M6, where 
Table 5

Values of environmental factors measured at different sampling stations in the Mar Menor lagoon

\begin{tabular}{|c|c|c|c|c|c|c|c|c|c|c|c|c|c|c|c|c|c|}
\hline & $\begin{array}{l}\mathrm{O}_{2} \\
(\mathrm{mg} / \mathrm{l})\end{array}$ & $\mathrm{pH}$ & $\begin{array}{l}\text { Tem- } \\
\text { perature } \\
\text { inter- } \\
\text { vale }\end{array}$ & $\begin{array}{l}\text { Sal- } \\
\text { inity } \\
\text { inter- } \\
\text { vale }\end{array}$ & $\begin{array}{l}\text { Suspen- } \\
\text { ded } \\
\text { material } \\
(\mathrm{mg} / \mathrm{l})\end{array}$ & $\begin{array}{l}\text { Hydrody- } \\
\text { namism }\end{array}$ & $\begin{array}{l}\text { Organic } \\
\text { material } \\
(\%)\end{array}$ & $\begin{array}{l}\text { Gravel } \\
(\%)\end{array}$ & $\begin{array}{l}\text { Sand } \\
(\%)\end{array}$ & $\begin{array}{l}\text { Silt } \\
(\%)\end{array}$ & $\begin{array}{l}\text { Clay } \\
(\%)\end{array}$ & $\begin{array}{l}\mathrm{Pb} \\
(\mathrm{pmm})\end{array}$ & $\begin{array}{l}\mathrm{Mn} \\
(\mathrm{pmm})\end{array}$ & $\begin{array}{l}\mathrm{Cu} \\
(\mathrm{pmm})\end{array}$ & $\begin{array}{l}\mathrm{Zn} \\
(\mathrm{pmm})\end{array}$ & $\begin{array}{l}\mathrm{Fe} \\
(\mathrm{mg} / \mathrm{g})\end{array}$ & $\begin{array}{l}\mathrm{Cd} \\
(\mathrm{pmm})\end{array}$ \\
\hline M1A & 7.86 & 7.85 & 16 & 3.68 & 0.04 & 9063 & 0 & 0 & 0 & 0 & 0 & 0 & 0 & 0 & 0 & 0 & 0 \\
\hline M1B & 6.33 & 8.35 & 16 & 3.68 & 0.07 & 9063 & 0 & 0 & 0 & 0 & 0 & 0 & 0 & 0 & 0 & 0 & 0 \\
\hline M1C & 20.35 & 8.16 & 16 & 3.68 & 0.02 & 9063 & 0 & 0 & 0 & 0 & 0 & 0 & 0 & 0 & 0 & 0 & 0 \\
\hline M1D & 15.64 & 7.67 & 16 & 3.68 & 0.11 & 9063 & 0 & 0 & 0 & 0 & 0 & 0 & 0 & 0 & 0 & 0 & 0 \\
\hline M2D & 10.09 & 8.11 & 16.3 & 2.71 & 0.08 & 1812 & 5.14 & 23.21 & 62.30 & 22.83 & 15.05 & 3300 & 980 & 45 & 3400 & 24.4 & 18 \\
\hline M3D & 12.82 & 8.14 & 15.5 & 3.18 & 0.24 & 38,854 & 0.49 & 6.14 & 84.30 & 0 & 5.7 & 1680 & 1000 & 32 & 1720 & 16.4 & 15 \\
\hline M4D & 12.05 & 8.21 & 13.7 & 2.5 & 0.03 & 24,000 & 0 & 0 & 0 & 0 & 0 & 0 & 0 & 0 & 0 & 0 & 0 \\
\hline M5B & 7.61 & 7.95 & 14.5 & 2.45 & 0.04 & 4800 & 0 & 0 & 0 & 0 & 0 & 0 & 0 & 0 & 0 & 0 & 0 \\
\hline M5C & 16.76 & 7.95 & 14.5 & 2.45 & 0.06 & 4800 & 0 & 0 & 0 & 0 & 0 & 0 & 0 & 0 & 0 & 0 & 0 \\
\hline M5D & 13.42 & 8.06 & 14.5 & 2.45 & 0.06 & 4800 & 0 & 0 & 0 & 0 & 0 & 0 & 0 & 0 & 0 & 0 & 0 \\
\hline M6A & 5.98 & 8.09 & 14.3 & 2.43 & 0.05 & 4800 & 5.81 & 0 & 50.35 & 29.69 & 19.97 & 1560 & 440 & 31 & 2100 & 21.1 & 17 \\
\hline M6C & 7.1 & 7.96 & 14.3 & 2.43 & 0.13 & 4800 & 7.68 & 0 & 52.41 & 26.57 & 21.03 & 1560 & 440 & 31 & 2100 & 21.1 & 17 \\
\hline M6D & 13.42 & 8.1 & 14.3 & 2.43 & 0.15 & 4800 & 6.72 & 7.46 & 55.43 & 23.28 & 22.29 & 1560 & 440 & 31 & 2100 & 21.1 & 17 \\
\hline M7D & 10.6 & 8.14 & 14.5 & 1.44 & 0.09 & 16,407 & 0 & 0 & 0 & 0 & 0 & 0 & 0 & 0 & 0 & 0 & 0 \\
\hline M8D & 9.66 & 8.12 & 15 & 1.01 & 0.10 & 16,407 & 0.32 & 2.47 & 95.04 & 3.97 & 0.99 & 380 & 492 & 15 & 410 & 3.3 & 17 \\
\hline M9D & 4.04 & 8.12 & 12.5 & 43.74 & 0.15 & 16,407 & 0.20 & 0.05 & 96.04 & 0.49 & 3.46 & 450 & 570 & 15 & 400 & 4.3 & 12 \\
\hline $\begin{array}{l}\text { M10- } \\
\text { D }\end{array}$ & 16.07 & 7.54 & 13.5 & 1.36 & 0.08 & 28,042 & 0 & 0 & 0 & 0 & 0 & 0 & 0 & 0 & 0 & 0 & 0 \\
\hline $\begin{array}{l}\text { M11- } \\
\text { D }\end{array}$ & 7.5 & 8 & 16.7 & 1 & 0.15 & 22,107 & 0.22 & 5.34 & 94.17 & 1.88 & 1.94 & 1205 & 362 & 40 & 1700 & 21.1 & 20 \\
\hline
\end{tabular}


organic matter content in sediments reach values higher than $5 \%$. Both stations have soft bottoms covered by mixed Cymodocea-Caulerpa meadows.

On the other hand, stations M7 and M10 on rocky substrate, located near an urban effluent, can be considered as affected by organic enrichment and are characterized by the presence of nitrophyle communities (although, due to lack of physical and chemical data confirming point, we decided not to take into account these two stations in the quantitative analysis).

The two-dimensional MDS configuration is shown in Fig. 3. ANOSIM results distinguish the stations of different substratum $(R=0.553, P=0.001)$. Once observed that differentiation of the stations, an MDS analysis was again applied to test whether there was a separation among the stations subject to organic enrichment (Figs. 4 and 5). ANOSIM results showed that such differentiation only exists in the case of the soft-bottom substratum $(R=0.72 ; P<0.05)$ indicating that the organic enrichment is one of the structural parameter of the communities. Moreover, in the case of the soft bottom stations, ANOSIM test establish four groups $\left(R_{\text {global }}=0.93 ; P<0.05\right)$ coinciding with the type of community (sts M3 and M8: Cymodoce meadow community, sts M6 and M2: Cymodoce-Caulerpa meadow community; M11: dredgued area; M9: area with phoraneids).

According to the hypothesis tested by Marques et al. [8] one should expect that the exergy index should be able to reflect pollution effects, in this case organic enrichment, with the lowest values being found in the stations mentioned above in comparison to other sites in the study area. This was in fact

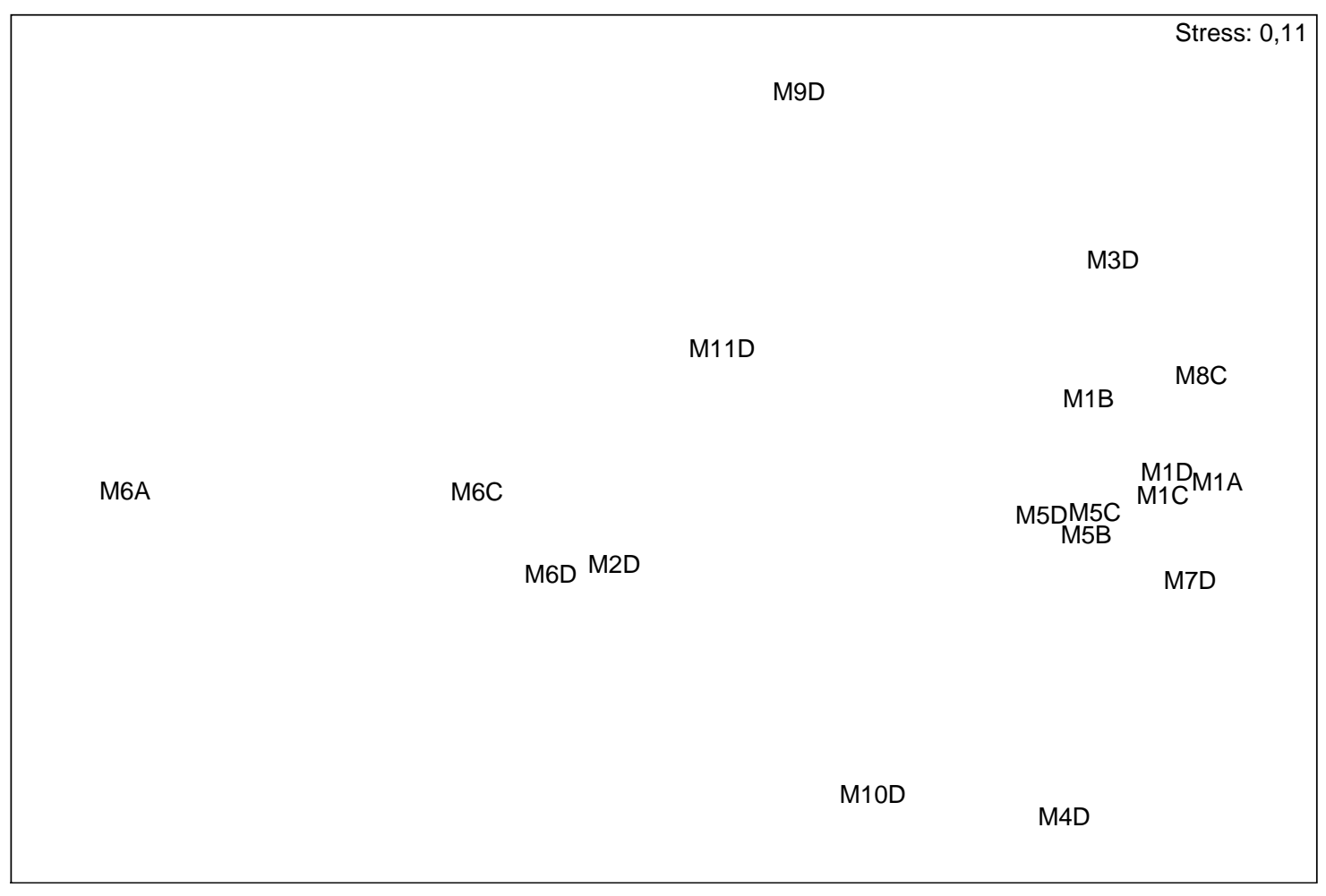

Fig. 3. Two-dimensional MDS plot of taxa abundance data of the 18 stations. 


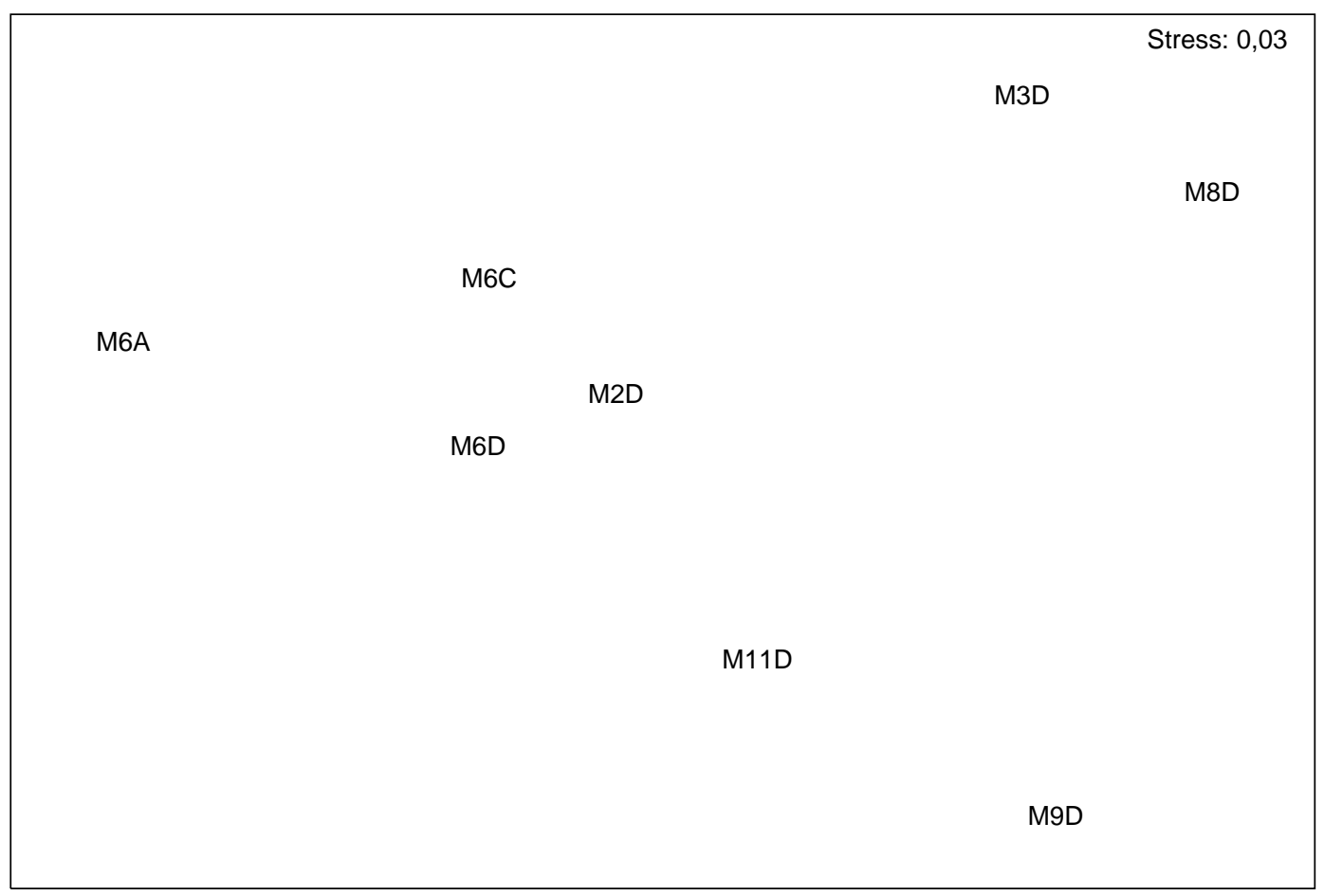

Fig. 4. Two-dimensional MDS plot of taxa abundance data of stations on soft bottom substratum.

confirmed in the case of soft bottoms stations (M2 and M6) (Table 6), although our observations do not show the same trend with regards to stations located on rocky substrates (Table 7).

Stations M2 and M6 have in common the presence of a taxonomic group, the polychaetes, which is dominated by Heteromastus filiformis, an opportunist species that lives buried in shallow muddy sand zones or in areas where marine vegetation detritus are abundant [32]. Various authors mention this species as an organic pollution indicator [33-35].

We used the Pearson's correlation coefficient to analyse possible relationships between the organic matter content in soft sediments and the values estimated for the exergy index. A negative significant $(r=-0.49, P \leq 0.05)$ correlation was found.

Specific exergy does not show any significant relation with amount of organic matter in the sediment (Table 8).

The variation of the exergy index as a function of the concentrations of heavy metals was very dependant on the metal. For instance, one could hypothesise that the low values of the exergy index measured in st. M3 could be related to a high concentration of $\mathrm{Pb}$ in the sediments (1680 ppm), but actually there was no significant correlation.

However, specific exergy does show apparently a clear response to certain heavy metals, e.g. $\mathrm{Pb}$ and Zn. Pearson's correlation coefficients show these two metals positively related with the specific exergy value (Table 8). Results, at first sight, may lead one to think that specific exergy increases when $\mathrm{Pb}$ and $\mathrm{Zn}$ occur in the sediment. Yet, a more accurate look at data leads us to the conclusion that the gravel proportion in sediments determines the structural exergy value. M2 and M6D have the highest gravel 


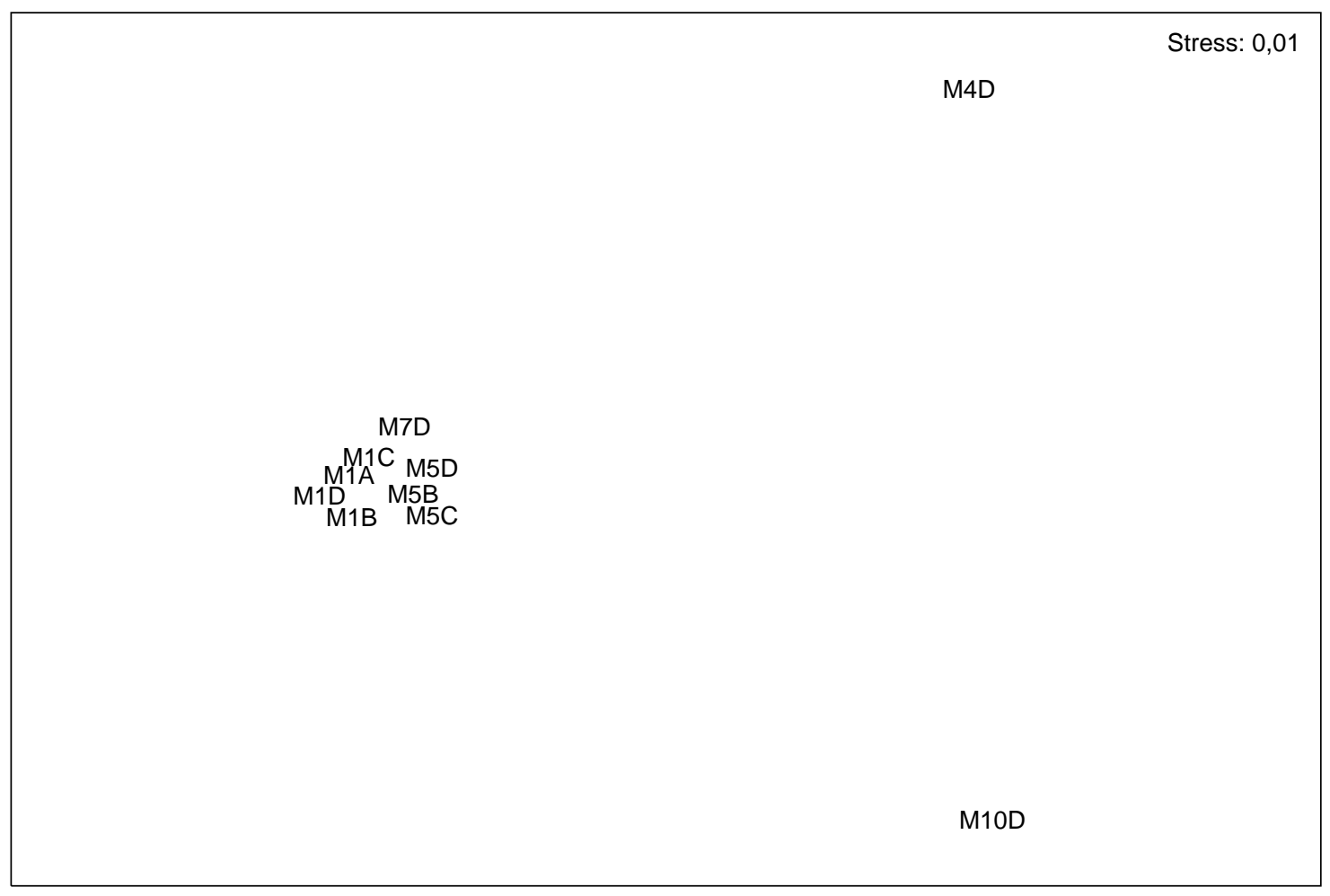

Fig. 5. Two-dimensional MDS plot of taxa abundance data of the stations on rocky substratum.

proportions in sediment and, at the same time, the highest $\mathrm{Pb}$ and $\mathrm{Zn}$ quantities. But M6 granulometric composition varies along the different seasons of the year, while the amount of toxics remains constant. It is in spring time when station M6 reaches the highest gravel proportion compared to the rest of seasons, and the specific exergy value is higher in comparison to autumn and summer time.

Taking into account another type of environmental variables, it is interesting that, with regard to soft bottom communities, the values of the exergy index appeared significantly influenced by the salinity interval. The factor that affected exergy values for rocky substrate communities most was

Table 6

Values Exergy, specific exergy, Shannon and Margalef indices in stations on soft substratum

\begin{tabular}{lcclr}
\hline Station & $\begin{array}{l}\text { Exergy }\left(\mathrm{g} \mathrm{m}^{2} \text { det, }\right. \\
\text { energy equiv) }\end{array}$ & Specific exergy & $\begin{array}{l}\text { Shannon-Wiener } \\
\text { (bits/ind) }\end{array}$ & Margalef \\
\hline M2D & $15,762,446$ & 603,402 & 2.75 & 5.34 \\
M3D & 211,020 & 1592 & 2.06 & 7.79 \\
M6A & 285,182 & 14,990 & 0 & 1.28 \\
M6C & 94,659 & 92,702 & 1.44 & 4.61 \\
M6D & $1,555,244$ & 109,065 & 1.9 & 8.49 \\
M8D & $70,381,987$ & 67,160 & 3.54 & 10.05 \\
M9D & $2,523,455$ & 14,250 & 2.75 & 8.32 \\
M11D & $28,713,101$ & 78,518 & 3.75 & 12.16 \\
\hline
\end{tabular}


Table 7

Values of the exergy, specific exergy, Shannon, and Margalef indices in stations on rocky substratum

\begin{tabular}{lccrr}
\hline Station & $\begin{array}{l}\text { Exergy }\left(\mathrm{g} \mathrm{m}^{2} \text { det, }\right. \\
\text { energy equiv) }\end{array}$ & Specific exergy & $\begin{array}{l}\text { Shannon-Wiener } \\
\text { (bits/indv) }\end{array}$ & Margalef \\
\hline M1A & $2,885,503,836$ & 149,346 & 2.23 & 8.83 \\
M1B & $183,671,203$ & 155,184 & 3.62 & 11.64 \\
M1C & $546,460,384$ & 76,725 & 2.19 & 9.44 \\
M1D & $192,624,681$ & 70,963 & 2.43 & 10.77 \\
M4D & $1,412,666,1509$ & 69,967 & 2.14 & 4.98 \\
M5B & $899,957,796$ & 109,861 & 2.55 & 8.15 \\
M5C & $76,867,912$ & 102,457 & 2.55 & 8.15 \\
M5D & $145,227,127$ & 94,642 & 2.45 & 9.2 \\
M7D & $324,967,2701$ & 94,686 & 1.99 & 6.05 \\
M10D & $301,455,400$ & 70,064 & 2.79 & 4.96 \\
\hline
\end{tabular}

Table 8

Values obtained after the application of Pearson's correlations between the different indices and the different environmental variables in stations on soft substratum

\begin{tabular}{|c|c|c|c|c|c|c|c|c|}
\hline & $\begin{array}{l}\text { Interval of } \\
\text { salinity }\end{array}$ & $\begin{array}{l}\text { Interval of } \\
\text { tempera- } \\
\text { ture }\end{array}$ & $\begin{array}{l}\text { Hydrody- } \\
\text { namism }\end{array}$ & Gravel $(\%)$ & Sand $(\%)$ & Silt (\%) & & \\
\hline \multirow{6}{*}{$\begin{array}{l}\text { Exergy } \\
\text { Specific } \\
\text { exergy } \\
\text { Shannon } \\
\text { Margalef } \\
\text { Specific } \\
\text { richness }\end{array}$} & $-0.60 *$ & +0.02 & +0.10 & +0.02 & +0.12 & \multicolumn{3}{|l|}{-0.39} \\
\hline & +0.27 & +0.50 & -0.47 & $+0.92 *$ & +0.23 & \multicolumn{2}{|l|}{-0.32} & \\
\hline & $-0.61 *$ & +0.40 & +0.34 & +0.27 & +0.60 & \multicolumn{2}{|l|}{$-0.70 *$} & \\
\hline & $-0.60 *$ & +0.28 & +0.51 & +0.006 & +0.57 & \multicolumn{2}{|l|}{$-0.77 *$} & \\
\hline & $-0.66^{*}$ & +0.50 & +0.34 & +0.07 & +0.39 & \multicolumn{2}{|l|}{-0.56} & \\
\hline & $\begin{array}{l}\text { Organic } \\
\text { matter } \\
\text { material }\end{array}$ & $\mathrm{Cd}$ & $\mathrm{Pb}$ & $\mathrm{Cu}$ & $\mathrm{Mn}$ & $\mathrm{Zn}$ & $\begin{array}{l}\text { Dissolved } \\
\text { oxygen }\end{array}$ & Suspension \\
\hline \multirow{6}{*}{$\begin{array}{l}\text { Exergy } \\
\text { Specific } \\
\text { exergy } \\
\text { Shannon } \\
\text { Margalef } \\
\text { Specific } \\
\text { richness }\end{array}$} & $-0.49 *$ & 0.33 & -0.36 & -0.31 & -0.17 & \multirow{2}{*}{$\begin{array}{l}-0.42 \\
+0.71 *\end{array}$} & \multirow{2}{*}{$\begin{array}{l}+0.06 \\
+0.20\end{array}$} & -0.22 \\
\hline & 0.30 & +0.35 & $+0.81 *$ & +0.60 & +0.50 & & & -0.38 \\
\hline & $-0.67 *$ & 0.14 & -0.22 & -0.09 & \multirow{3}{*}{$\begin{array}{r}0.06 \\
-0.13 \\
-0.25\end{array}$} & \multirow{3}{*}{$\begin{array}{l}-0.34 \\
-0.48 \\
-0.28\end{array}$} & +0.09 & \multirow{3}{*}{$\begin{array}{l}+0.26 \\
+0.50 \\
+0.12\end{array}$} \\
\hline & $-0.68 *$ & 0.11 & -0.44 & -0.17 & & & +0.22 & \\
\hline & $-0.61 *$ & 0.51 & -0.22 & 0.06 & & & +0.03 & \\
\hline & \multicolumn{2}{|r|}{ Exergy } & \multicolumn{2}{|c|}{ Specific exergy } & \multicolumn{2}{|c|}{ Shannon } & \multicolumn{2}{|c|}{ Margalef } \\
\hline \multicolumn{2}{|c|}{ Specific exergy } & \multicolumn{3}{|l|}{+0.05} & & & \\
\hline \multirow{2}{*}{\multicolumn{2}{|c|}{$\begin{array}{l}\text { Shannon } \\
\text { Margalef }\end{array}$}} & +0.66 & \multicolumn{2}{|c|}{+0.20} & & & & \\
\hline & & +0.52 & & & +0 & & & \\
\hline \multicolumn{2}{|c|}{ Specific richness } & $+0.71 *$ & & 01 & +0 & & +0.83 & \\
\hline
\end{tabular}

$P \leq 0.05$. 
Table 9

Values obtained after the application of Pearson's correlations between the different indices and different environmental variables in stations on rocky substratum

\begin{tabular}{|c|c|c|c|c|c|}
\hline & Hydrodynamism & $\begin{array}{l}\text { Interval of sal- } \\
\text { inity }\end{array}$ & $\begin{array}{l}\text { Interval of tem- } \\
\text { perature }\end{array}$ & $\begin{array}{l}\text { Suspended } \\
\text { material }\end{array}$ & Dissolved oxygen \\
\hline Exergy & +0.53 & -0.13 & -0.48 & -0.40 & -0.16 \\
\hline Especific exergy & -0.13 & +0.39 & +0.36 & -0.18 & -0.47 \\
\hline Shannon & -0.10 & +0.20 & +0.28 & +0.20 & -0.32 \\
\hline Margalef & -0.76 & +0.81 & $+0.82 *$ & +0.10 & -0.12 \\
\hline \multirow[t]{2}{*}{ Specific richness } & -0.23 & +0.57 & +0.41 & -0.18 & +0.23 \\
\hline & Exergy & \multicolumn{2}{|c|}{ Specific exergy } & Shannon & Margalef \\
\hline Specific exergy & -0.04 & & & & \\
\hline Shannon & -0.40 & +0.55 & & & \\
\hline Margalef & -0.56 & +0.34 & +0 & & \\
\hline SPECIFIC richness & $+0.53 *$ & +0.21 & +0 & & $+0.62 *$ \\
\hline
\end{tabular}

$P \leq 0.05$.

hydrodynamism. This might explain low values of the exergy index estimated in st M3, where the salinity interval is larger (3.2).

The two diversity indices and the exergy index behaved in a very similar way (showing a significant positive correlation) in describing the state of the soft bottom communities. The lowest values for the Shannon-Wiener and the Margalef indices were found in st M6, and both indices showed also low values in st M3. Nevertheless, the two diversity indices appeared to be more sensible to the influence of organic matter content in sediments than the exergy index (Table 8). On the other hand, none of the diversity indices respond to the concentration of heavy metals, although both appear to be influenced by the granulometry, and the salinity interval.

On rocky substrates, the different indices did not follow the same pattern regarding their spatial distribution. In general, the values estimated for the exergy index and the specific exergy index were clearly higher on rocky substrates than on soft bottoms, which suggests a higher sensibility to distinguish between different kinds of substrates than the Shannon-Wiener and Margalef indices.

On the other hand, the exergy index and, as one should expect, the diversity indices, were positively correlated to the number of species in the community (Tables 8 and 9).

In general, in that sense, it could be thought that, as well as the Shannon and Margalef indices, the exergy index is an indicator of the structure of the community which to a small or grant extent depends on the number of species and their capability to colonize a certain environment.

\section{Discussion}

Table 10 shows a resume of the response of each one of the indices studied in this research.

We can say that the confluence of structural parameters of the communities in the Mar Menor produces that none of the applied indices clearly respond to the organic enrichment and that they do not behave in such a way they were designed for, indicators of the structure of the communities, without being specific of any type of disturbance. 
Table 10

Resume of the response of each one of the indices studied in this work

\begin{tabular}{|c|c|c|c|c|c|c|c|c|c|}
\hline & $\begin{array}{l}\text { Organic } \\
\text { matter } \\
(\%)\end{array}$ & $\begin{array}{l}\text { Interval } \\
\text { of salinity }\end{array}$ & $\begin{array}{l}\text { Interval } \\
\text { of tem- } \\
\text { perature }\end{array}$ & $\begin{array}{l}\text { Hydrody- } \\
\text { namism }\end{array}$ & $\begin{array}{l}\text { Dissolved } \\
\text { oxygen }\end{array}$ & $\begin{array}{l}\text { Suspen- } \\
\text { sion } \\
\text { material }\end{array}$ & $\begin{array}{l}\text { Granulo- } \\
\text { metry }\end{array}$ & $\begin{array}{l}\text { Heavy } \\
\text { metals }\end{array}$ & $\begin{array}{l}\text { Susbtra- } \\
\text { tum }\end{array}$ \\
\hline Exergy & + & + & - & - & - & - & - & - & + \\
\hline $\begin{array}{l}\text { Specific } \\
\text { exergy }\end{array}$ & - & - & - & - & - & - & + & + & + \\
\hline Shannon & + & + & - & - & - & - & + & - & + \\
\hline Margalef & + & + & - & - & - & - & + & - & + \\
\hline
\end{tabular}

As a whole, our results suggest the conclusion that the exergy index, as ecological indicator, captures, in fact, useful information about the state of the community, in response to structural environmental variables of the system studied such as organic matter, salinity interval, or in the case of specific exergy, granulometry. However, the exergy index cannot provide, explicit information about disturbed (e.g. polluted) scenarios.

Nevertheless, in the study carried out by Marques et al. [8] in the Mondego estuary (Portugal), both exergy based indicators were able to distinguish between areas with different eutrophication symptoms. Differences in efficiency in both case studies might have been due to the fact that in the Mar Menor lagoon the effects of organic pollution are in a certain extent diluted among other system-structuring factors, while in the south arm of the Mondego estuary eutrophication is the major driving force behind the ongoing changes.

In the same work, regarding diversity measures, results showed that the Margalef index as distinguished between different eutrophication levels. Meanwhile, the Shannon-Wiener index was influenced too much by the dominance of certain species (e.g. H. ulvae) whose presence has no relation with any type of disturbance or pollution phenomenon, being rather favoured by abundant food resources. In the case of Mar Menor lagoon, the Shannon-Wiener and Margalef indices patterns are similar.

On the other hand, the two diversity indices used and the exergy, show a dependency on the number of species. This dependency is obvious in the case of the diversity indices due to their own formulation due to the Margalef index is based on the number of species per unit of a defined sample and the ShannonWiener index relates species richness and evenness in a simple expression. Nevertheless, the dependency of exergy on the number of species is more difficult to enlighten.

A possible explanation, for instance taking into account data on soft bottom substrates, could be the fact that the total biomass (standing stock) and the number of species are often correlated. If this is the case, the sensibility of the exergy index, for instance to the composition of the community, must be considered insufficient and, as referred by Marques et al. [8], there is a need for determining more discrete values of the weighing factors used to estimate the exergy index from organisms biomass.

There are proposals on how to achieve this. For instance, Marques et al. [8], with regard to exergy estimations based on the biomass of organisms and the thermodynamic information due to genes [14], claim that the use of the amount of DNA per cell nucleus instead of the number of genes may be more practical to characterise different organisms. These authors argue that, in fact, genetic mapping available in published data is very scarce, and most of the organisms in biotic systems have not been characterised owing to the long time procedures and high costs involved in the molecular work of gene analysis. 
Afterwards, Fonseca et al. [25] described a possible methodology to estimate the weighing factors in a relatively simple way, based on the analysis of DNA contents ( $C$-values) of several groups of organisms by flow cytometry. Moreover, these authors discuss their approach in theoretical and practical aspects, concerning reliability and eventual application in ecological studies.

We may say that the exergy index, in practice, is still not applicable as ecological indicator in a generalized way in the field of environmental management. Nevertheless, a number of examples of application of thermodynamic principles, including the exergy concept, for functional analysis and evaluation of ecosystems have been reported in literature, regarding ecological structures and balances of lakes, evaluation of terrestrial systems, and agro-ecosystems [8,9]. But to validate the high value of the exergy index as explanatory and integrative tool it will be necessary to interpret as many empirical observations as possible, as well as design empirical experiments capable to test the theoretical framework behind the application of the exergy concept in ecology.

\section{Conclusions}

As a whole, our results suggest that the exergy index is able to capture useful information about the state of the community. In fact, more than a simple description of the environmental state of a system, variations of the exergy index may provide us a much better understanding of the system development in the scope of a broader theoretical framework. However, at the present stage, the exergy index is still not applicable as ecological indicator in environmental management.

\section{References}

[1] Nelson WG. Prospects for development of an index of biotic integrity for valuating habitat degradation in coastal systems. Chem Ecol 1990;4:197-210.

[2] Blandin P. Bioindicateurs et diagnostic des systemes ecológiques. Bull Ecol 1986;17(4):1-307.

[3] O'Connor JS, Dewling RT. Indices of marine degradation: their utility. Environ Manage 1986;10:335-43.

[4] Salas F. Valoración y aplicabilidad de los índices e indicadores biológicos de contaminación orgánica en la gestión del medio marino. Tesis de doctorado. Murcia: Universidad de Murcia; 2002

[5] Warwick RM. Environmental impact studies on marine communities: pragmatical considerations. Aust J Ecol 1993;18: 63-80.

[6] Jørgensen SH, Mejer H. A holistic approach to ecological modelling. Ecol Modell 1979;7:169-89.

[7] Jørgensen S. Integration of ecosystem: a pattern. Dordrecht: Kluwer; 2002.

[8] Marques JC, Pardal MA, Nielsen SN, Jorgensen SE. Analysis of the properties of exergy and biodiversity along an estuarine gradient of eutrophication. Ecol Modell 1997;102:155-67.

[9] Marques JC, Nielsen SN, Jørgensen SE. Applying thermodynamic orientors: the use of exergy as an indicator in environmental management. In: Müller F, Leupelt M, editors. Ecotargets, goal functions, and orientors. Theoretical concepts and interdisciplinary fundamentals for an integrated, system-based environmental management. Berlin: Springer; 1998. p. 41-9.

[10] Nielsen SN. Application of exergy in structural-dynamical modelling. Vehr Int Ver Limnol 1990;24:641-5.

[11] Jorgensen SE. Review and comparison of goal functions in system ecology. Vie Mileu 1994;44(1):11-20.

[12] Fuliu Xu. Exergy and structural exergy as ecological indicators for the state of the Lake Chalou ecosystem. Ecoll Modell 1997;99:41-9.

[13] Jørgensen SE. State of the art of ecological modelling. In: McAleer M, editor. Proceedings of the international congress on modelling and simulation. Sydney: University of Western Australia 2000. p. 455-81. 
[14] Jørgensen SE, Nielsen SN, Mejer H. Emergy, environment, exergy and ecological modelling. Ecol Modell 1995;77: 99-109.

[15] Nielsen SN. Strategies for structural dynamics modelling. Ecol Modell 1992;63:91-101.

[16] Nielsen SN. Modelling structural dynamic changes in a Danish Shallow Lake. Ecol Modell 1994;73:13-30.

[17] Jorgensen SE, Padisak J. Does the intermediate disturbance hypothesis comply with thermodynamics? Hydrobiologia 1996;323:9-21.

[18] GESAMP (IMO/FAO/UNESCO-IOC/WMO/WHO/IAEA/UN/UNEP Joint Group of Experts on the Scientific Aspects of Marine Environmental Protection). The health of the oceans. Rep. Stud. GESAMP, 16; 1978. p. 113.

[19] Chapman HD, Pratt PF. Métodos de análisis para suelos, plantas y aguas. México, 1972 D.F: Trillas.

[20] Riviere A. Méthodes granulometriques. Techniques et interprétations 1977.

[21] Marcos C. Capacidad de uso de los suelos de isla de Lanzarote. Santa Cruz de Tenerife: Consejería de Obras Públicas, Gobierno de Canarias; 1986.

[22] Buchanan JB. Sediment analysis. In: Holme NA, McIntyre AD, editors. Methods for the study of marine benthos. Oxford: Blackwell; 1984. p. 41-65.

[23] Marcos C. Planificación ecológica y ordenación del territorio en el litoral. Tesis de Doctorado. Universidad de Murcia; 1991.

[24] Keddy PA. Quantifying a within-lake gradient of wave energy in Gillfillan Lake. Nova Escotia Can J Bot 1983;62:301-9.

[25] Pérez Ruzafa A. Estudio ecológico y bonómico de los poblamientos bentónicos del Mar Menor (Murcia, SE de España). Tesis doctoral. Universidad de Murcia; 1989.

[26] Fonseca JC, Marques JC, Paiva AA, Freitas AM, Madeira VMC, Jørgensen SE. Nuclear DNA in the determination of weighing factors to estimate exergy from organisms biomass. Ecol Modell 2000;126:179-89.

[27] MacGregor HC. Big chrimossomes and speciation amongst Amphibia. In: Dover GA, Flavell RB, editors. Genome evolution. New York: Academic Press.

[28] Gold JR, Ragland CJ, Woolley JB. Evolution of genome size in North American fishes. In: Mayden RL, editor. Systematic, historical ecology and North American freswater fishes. Stanford, CA: Stanford University Press. p. 23-41.

[29] Levin B. Genes V. New York: Oxford University Press; 1994.

[30] Jørgensen SE, Marques JC. Thermodynamics and ecosystem theory, case studies from hydrobiology. Hydrobiologia 2001; 445:1-10.

[31] Murray BG. Are ecological and evolutionary theories scientific? Biol Rev 2001;76:255-89.

[32] Fauvel P. Faune de France (16). Polychetes sedentaries. Nendeln: Kraus-Thomson; 1977.

[33] Gray JS. Pollution induced changes in populations. Philos Trans R Soc London 1979;286:545-61.

[34] Bellan G. Pollution et peuplements bentiques sur substrat meuble dans la region de Marseille.1-Le secteur de Cortiou. Rev Int Oceanogr Mediterranean 1967;6:53-87.

[35] Bellan G. Annélides polychétes des substrats solids de troits mileux pollués sur les cortes de provence (France): Cortou, Golfe de Fos, Vieux Port de Marseille. Téthys 1980;9:260-78. 